\title{
Aspectos históricos e contextuais de possível interesse para a discussão do sucesso da teledramaturgia brasileira
}

\author{
Historical and contextual aspects of possible interest for the discussion
} of Brazilian television dramaturgy success

http://dx.doi.org/10.5007/2178-4582.2014v48n1p55

\author{
Paulo Rogério Meira Menandro \\ Universidade Federal do Espírito Santo, Vitória/ES, Brasil
}

Cinthia Ferreira de Souza

Faculdade Pitágoras, Grarapari/ES, Brasil

\begin{abstract}
$\mathrm{O}$ artigo discute o papel da telenovelas no contexto brasileiro, considerando as características com que esse tipo de produção ficcional passou a ser desenvolvido nas últimas décadas. A partir do exame da literatura pertinente são apresentados aspectos históricos de interesse para a discussão do tema e são buscados elementos que ajudem a explicar o sucesso popular das telenovelas ao longo de meio século no Brasil. É construído o argumento de que a centralidade de questões sobre a realidade e transformações da família brasileira representadas nas telenovelas é aspecto fundamental para a compreensão do sucesso e longevidade dessa modalidade de produção ficcional que marca a cultura do país.
\end{abstract}

Palavras-chave: Telenovela - Família - Relações conjugais - Moralidade - Vida cotidiana
The article discusses the role of soap operas in the Brazilian context, considering the features that this sort of fictional production started to be developed in recent decades. From the analysis of relevant literature, historical aspects of interest are presented for the discussion of the theme, and also elements are searched to explain why popular soap operas are so successful over half a century in Brazil. It is built the argument that the centrality of issues concerning to the reality of Brazilian family transformations depicted by the soap operas is essential to understand the success and longevity of such modality of fictional production which so much marks the country's culture.

Keywords: Soap opera - Family - Conjugal relationships - Morality - Daily life.

\section{Introdução}

Há quase duas décadas, referindo-se à ficção televisiva produzida no Brasil, Marcondes Filho (1994, p. 40) afirmou que a telenovela "é tão cotidiana quanto a própria vida. As pessoas acompanham-na e depois passam o resto do dia pensando nela, para depois vê-la outra vez no dia seguinte. Tornou-se um componente necessário da existência, uma espécie de preenchimento da necessidade de vivência" E acrescenta: ela "faz parte, domina e preenche o cotidiano das pessoas, e, na maioria dos casos, de forma mais rica, densa e emocionante do que a própria vida" (Ibid., p. 45). É interessante ressaltar que o autor fazia referência a uma modalidade de produção cultural que, nos mesmos moldes de veiculação de capítulos diários conhecidos hoje, já acumulava trinta anos de existência na época em que ele escreveu. 
Ao discutir o importante papel das telenovelas no cotidiano do brasileiro quase na mesma época do texto acima citado, Hamburger (1998) reuniu diversos dados e argumentos com os quais assinala a enorme força dessa teledramaturgia nacional, uma vez que os temas que aborda extrapolam aspectos típicos nacionais ou regionais, constituindo produto passível de exportação para outras realidades culturais com nível de aceitação muito expressivo.

Em texto que integra um grande compêndio de história internacional da televisão, também da mesma época dos trabalhos já citados, Paterson (1995, p. 106) mencionou o enorme sucesso das telenovelas brasileiras, inclusive em mercados além-mar uma vez que são exportadas para mais de uma centena de países, destacando que está "incluído um inusual padrão de colonização reversa vis-à-vis Portugal", um dos muitos países em que as novelas brasileiras despertam grande interesse. No mesmo compêndio, a importância da ficção televisiva brasileira também foi reconhecida por Berwanger (1995), que avaliou que as novelas do Brasil são basicamente soap operas, ainda que em estilo brasileiro, mas que as diferenças entre elas são fáceis de ver e difíceis de descrever. Ele destacou como característica diferenciadora da telenovela brasileira o fato de os capítulos serem produzidos apenas alguns dias antes da transmissão e que nesse processo "são levadas em conta as reações da audiência aos capítulos imediatamente anteriores" (BERWANGER, 1995, p. 319).

As afirmações registradas acima são todas perfeitamente atuais. A audiência das telenovelas continua se configurando como a mais expressiva no mais popular dos meios de comunicação de massa. Em texto recente, Lopes (2009) descreve o quadro atual de forma interessante e detalhada - o que justifica a longa citação que se segue -, ficando bem caracterizado que a importância da telenovela é tão marcante ao ponto dela estar presente em inúmeras facetas da vida dos brasileiros:

Tão importante quanto o ritual diário de assistir os capítulos das novelas é a informação e os comentários que atingem a todos, mesmo àqueles que só de vez em quando ou raramente as assistem. As pessoas, independentemente de classe, sexo, idade ou região acabam participando do território de circulação dos sentidos das novelas, formado por inúmeros circuitos onde são reelaborados e ressemantizados. Esse fenômeno leva-me a afirmar que 'a novela é tão vista quanto falada', pois seus significados resultam tanto da narrativa audiovisual produzida pela televisão quanto da interminável conversação produzida pelas pessoas. Como muitas pesquisas já mostraram, a novela começa a ser comentada durante o próprio ato de sua assistência. Conversa-se sobre ela em casa, com o marido, a mãe, os filhos, a empregada, com os vizinhos, os amigos, no trabalho. Fala-se dela nas revistas especializadas em comentários e fofocas sobre novelas; em colunas dos jornais diários, tanto os de prestígio como os populares; nas pesquisas de opinião feitas por institutos; nas cartas de leitores enviadas aos jornais e revistas; nos programas de televisão e rádio que acompanham as novelas 
tanto em forma de reportagem e entrevistas com seus atores, como em programas de humor onde elas são satirizadas. A novela também aparece nas músicas dos CDs de trilhas sonoras especialmente compostas; ela está presente em todo um circuito de merchandising, das roupas e jóias usadas pelos atores aos objetos de decoração dos cenários, bebidas, carros, lojas e bancos que aparecem nas histórias; nos comerciais com os atores das novelas que estão no ar. Finalmente, o mais novo espaço ocupado por toda essa conversação que a novela provoca é a internet, onde cada uma tem seu site (informado no ar ao final da ficha técnica que encerra cada capítulo diário). As opiniões dos fãs são expressas em inúmeras listas de discussão, posts e blogs, dos autores e do público, e onde inúmeros dispositivos de interatividade ampliam e renovam os significados das novelas (LOPES, 2009, p. 29/30).

Embutido na citação acima está um aspecto destacado por Dejavite (1999): a própria mídia impressa autentica a importância da telenovela como um dos produtos da indústria cultural brasileira significativos para a vida social. Questões abordadas na trama amiúde fornecem pautas para matérias de jornais e revistas. Acontecimentos que se passaram na novela são muitas vezes tratados como material jornalístico.

É possível que aspectos da história das telenovelas contenham elementos com valor heurístico para a compreensão dessa realidade de enorme sucesso. Daí o objetivo da presente revisão: examinar e organizar informações de interesse histórico disponíveis na literatura especializada, relacionando-as, quando possível, ao seu contexto de ocorrência, buscando identificar aspectos que possam contribuir para a compreensão do prestígio das telenovelas junto à população brasileira.

\section{Informações de interesse para a história da telenovela}

Buitoni (1986) registra que, na primeira metade do século XIX, tornou-se parte importante das publicações jornalísticas uma seção na qual capítulos de romances se sucediam a cada edição - tipo de produção que se tornou conhecido como folhetim. Essa prática iniciou-se na França na primeira metade do Século XIX, como estratégia para atrair leitores. Torres (2003) ressalta que, já naquela época, o interesse da maior parte das pessoas pelo noticiário não superava o interesse pelo entretenimento. Buitoni (1986) ainda explica que o termo folhetim (feuilleton, no original francês), inicialmente indicava uma seção de variedades do jornal (seção que ocupava espaço similar ao de um grande rodapé), mas a ficção apresentada em capítulos tornou-se parte tão importante de tal seção que a palavra folhetim passou a designar as próprias narrativas seriadas. Cunha (1999, p. 32) esclarece que essa seção ao pé da página apresentava-se graficamente "sob um traço horizontal que a isolava e, ao mesmo tempo, lhe dava uma posição de destaque". 
Torres (2003) acrescenta que foi o editor do jornal francês La Presse, Émile de Girardin, quem resolveu utilizar esse rodapé do jornal para publicar os romances em capítulos. Tais narrativas seriadas (folhetins) também vieram a ser designadas em língua portuguesa como novelas, termo que se manteve válido para nomear os relatos românticos ou de aventuras, independentemente de sua apresentação ser feita em capítulos. O termo estendeu-se às histórias apresentadas com apoio de imagens fotográficas em formato cuja base está nas produções cinematográficas e nas histórias em quadrinhos (fotonovelas), assim como à produção televisiva de ficção seriada (telenovelas). Assim, não é despropositado considerar os folhetins como precursores longínquos da telenovela atual.

De acordo com Torres (Ibid.), o primeiro folhetim publicado dessa forma, em 1836, foi o romance anônimo Lazarillo de Tormes (conhecido desde o século XVI), seguido de A Menina Velha, de Honoré de Balzac que, por sua vez, foi sucedido por $O$ Conde de Monte Cristo, de Alexandre Dumas. Telles (1997) argumenta que o século XIX foi o século do romance, pois foi o período em que se cristalizou a importância do produto cultural "romance moderno" em coincidência com a ascensão da sociedade burguesa. Sua argumentação possibilita considerar os romances de folhetins como representantes de gênero literário precursor longínquo das telenovelas:

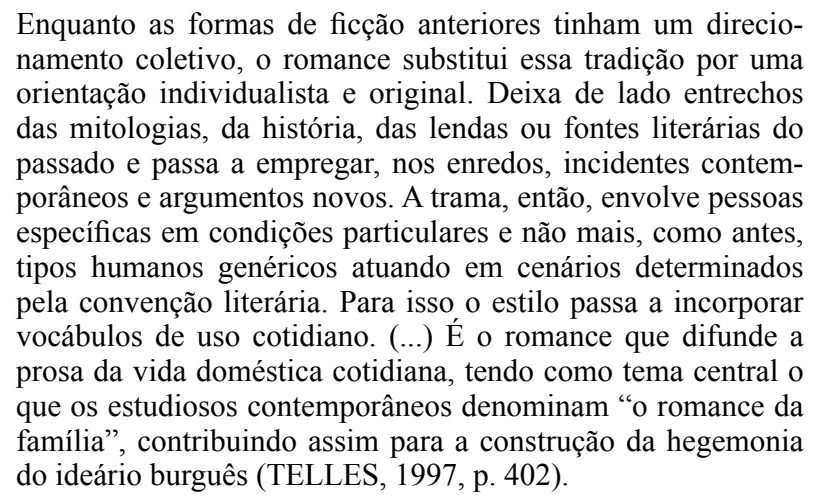

O Brasil importou de imediato a novidade do folhetim, pela via do Jornal do Commercio, do Rio de Janeiro, em 1839 (CUNHA, 1999). Passaram a ser publicados diariamente capítulos de obras literárias importadas, o que permite dizer que, durante algum tempo, aspectos cotidianos da sociedade brasileira não foram tratados. Buitoni registra que o primeiro folhetim publicado no Jornal do Commercio, traduzido do francês, chamava-se $O$ Capitão Paulo (BUITONI, 1986, p. 38). Após período relativamente curto, de cerca de cinco anos, começaram a ser publicados textos brasileiros. O romance Filho do Pescador, do fluminense Antônio Gonçalves Teixeira e Souza, um pioneiro da novela romântica brasileira, inaugurou a série de publicações de autores 
nacionais. Outros romancistas brasileiros valeram-se desse mesmo meio em diversas ocasiões, principalmente José de Alencar e Joaquim Manuel de Macedo (CUNHA, 1999).

Aspecto relevante é mencionado por Cunha ao relatar, citando estudo de Bicalho, que no século XIX havia no Brasil, entre mulheres alfabetizadas e que faziam parte de famílias sem dificuldades financeiras, a prática de promover momentos de leitura coletiva, na sala ou no quarto de costuras, e esses episódios propiciavam a troca de confidências e a discussão de assuntos familiares:

\begin{abstract}
Essa prática de leitura em voz alta em espaços domésticos possibilitava a emoção, o enternecimento, os bons sentimentos e ia construindo uma certa sensibilidade que tinha suas formas de expressão: provocava cenas de lágrimas coletivas, suspiros, devaneios, ódios, raivas e, o que é mais importante, permitia que as leitoras escancarassem a sua subjetividade, as suas emoções, vivenciando-as em conjunto (CUNHA, 1999, p. 31).
\end{abstract}

É importante estar atento ao fato de que a situação descrita, apesar de distante do período atual em mais de um século, certamente tem pontos de contato com determinadas configurações de espectadores de telenovelas. Considere-se, por exemplo, as seguintes considerações de Lopes, Borelli e Resende sobre a telenovela:

\begin{abstract}
Mesmo se propondo a ser fictícia, a telenovela não se separa da planície familiar que se estende em torno do análogo: retrata a visão íntima da sociedade, nos aspectos em que as pessoas estão, na realidade, preocupadas com as histórias de suas próprias vidas e com suas emoções particulares. A exposição da intimidade, na tela, cria um imaginário comum, catalisador e unificador de sonhos, desejos e fantasias; autoriza a revelação, metáfora da confissão, restitui a possibilidade de lidar com as expectativas mútuas, que se criam através da exposição do eu (LOPES; BORELLI; RESENDE, 2002, p. 196).
\end{abstract}

Após muito tempo surgiram as fotonovelas, que assumiram o romantismo e utilizaram recursos emprestados tanto do cinema como dos quadrinhos (sequências de fotos das cenas e diálogos apresentados em balões). A primeira revista de fotonovela publicada no país apareceu em 1947, pela Editora Vecchi, com o título Grande Hotel (HABERT, 1974). Essas revistas eram consideradas uma espécie de literatura marginal (TORRES, 2003), mas tinham grande apelo popular, tendo circulado no país muitos títulos com tiragens superiores a duzentos mil exemplares de cada número mensal no ano de 1970, como consta de estudo realizado em momento no qual as fotonovelas ainda detinham prestígio popular (HABERT, 1974). O exame dos conteúdos das fotonovelas revela evidentes similaridades com o universo temático das telenovelas, ainda que 
a extensão e a diversidade dos assuntos abordados em uma mesma fotonovela não possa ter a amplitude permitida a uma telenovela que se estende por vários meses. O esquema básico amor versus obstáculo está sempre presente. Habert (Ibid., p. 96) diz que "o amor é definido como uma força de eleição que torna possível a divisão entre heróis e vilões. O herói é aquele que exerce o papel amoroso e o vilão aquele que manipula o obstáculo".

A crítica de que a fotonovela é a repetição cansativa das mesmas histórias - crítica muitas vezes dirigida também à telenovela - não é totalmente verdadeira, segundo Habert. A autora assinala que as fotonovelas "têm desenvolvido todos os temas do repertório universal, inclusive os da atualidade, 'modernos', científicos" (HABERT, 1974, p. 93), citando fatos que foram incorporados como pano de fundo para muitas das histórias (como também acontece com as atuais telenovelas), como acontecimentos sensacionais retirados do noticiário internacional (assassinatos, escândalos, julgamentos), temas relativos à saúde e à ciência (por exemplo, transplante de coração), novidades em termos de comportamento (hippies, por exemplo), e grandes temas políticos culturais, como foi o caso da guerra do Vietnã. Com a massificação da televisão e de outras tecnologias de vídeo, a fotonovela perdeu importância e perdeu também seu interesse como objeto de pesquisa.

Antes das fotonovelas, mas também na década de 1940, surgiram no Brasil as radionovelas. Através do som a imaginação do ouvinte fluía tornando possível reconhecer o mocinho, a mocinha e o vilão da história. Em busca da felicidade, adaptada de um folhetim cubano de Leandro Blanco, foi a primeira novela brasileira transmitida pela Rádio Nacional do Rio de Janeiro, em 1942. Marques de Melo (1988) registra que as radionovelas que imperavam nas emissoras, de início, eram importadas de autores cubanos e mexicanos. Só no ano de inauguração da televisão brasileira, em 1951, a PRA-5 Rádio São Paulo lançou Fatalidade, primeira novela escrita por autor brasileiro: Oduvaldo Vianna.

Marques de Melo também assinala que as mencionadas características das radionovelas indicam que a telenovela brasileira emergiu de matrizes latinas, mas "ela, sem dúvida, tem raízes também na soap opera norte-americana, considerando que o gênero evoluiu em todo o continente sob o patrocínio das companhias produtoras de bens de limpeza e de beleza" (MARQUES DE MELO, 1988, p. 25). Mogadouro registra que havia a intenção de estabelecer um produto cultural que interessasse aos anunciantes, porque poderia promover a fidelidade do telespectador - o que de fato ocorreu uma vez que uma importante multinacional do setor elegeu a telenovela como "espaço ideal para a veiculação dos seus produtos e passou a financiar essa experiência, inclusive escolhendo elenco, roteiros e autores, até o final da década de 1960" (MOGADOURO, 2007, p. 89).

As radionovelas perderam espaço com a disseminação da televisão e com a ênfase radiofônica em notícias, música e serviços, facilitada pela inovação 
tecnológica da transmissão em freqüência modulada (FM), com melhor qualidade de som. O declínio do rádio se deve principalmente ao advento da televisão. Logo nos primeiros anos da TV brasileira surgiu o teleteatro no qual obras de teatro universal eram encenadas. Este gênero de programa de ficção chegou a ter grande prestígio. No Rio de Janeiro, por exemplo, se destacaram o Grande Teatro Tupi, o Teatro de Comédia, o Teatro Moinho de Ouro (TV Rio) e o Teatrinho Trol. Entre 1951 e 1952, há registros de peças escritas para a TV por autores como Henrique Pongetti e Lúcia Beneditti, entre outros. A teledramaturgia brasileira migrou aos poucos do teleteatro para as telenovelas. Em 1950 foi inaugurada a primeira emissora de televisão no Brasil, a TV Tupi de São Paulo. Em 1951 a emissora transmitia ao vivo, às terças e quintas feiras, o melodrama Sua vida me pertence.

A telenovela, portanto, começou a ser exibida na televisão brasileira logo após sua inauguração. Elas eram exibidas ao vivo, o que ocorria somente dois ou três dias por semana e com reduzido número de capítulos. O público ainda era muito pequeno, pois a compra de aparelhos televisivos só se popularizou na década de 1960. A partir de 1963 a introdução da tecnologia do videoteipe (video tape) facilitou a produção das novelas diárias em função da redução dos custos de produção que propiciava. No ano seguinte a TV Excelsior transmitiu 2-5499 Ocupado, do argentino Alberto Migre, a primeira novela diária exibida na televisão brasileira, importada da Argentina e estrelada por Glória Menezes e Tarcísio Meira (FADUL, 1999).

O primeiro grande sucesso de público ocorreu entre os anos de 1964 e 1965: a telenovela $O$ Direito de Nascer, do cubano Félix Caignet, que já havia sido transmitida há mais de dez anos como radionovela, com sucesso. Essa novela deu início à popularização do hábito brasileiro, que se mantém até hoje, de assistir a telenovela em determinado horário, identificado como horário nobre (Ibid., 1999). Nos anos 60, as telenovelas brasileiras ainda mantinham características das antigas radionovelas, assim como da teledramaturgia mexicana, já desenvolvida na época. O Brasil se inseria em uma indústria continental de produção de novelas. Textos cubanos eram adaptados na Argentina e no Brasil, e seguiam para a Venezuela. Escritores brasileiros do gênero passaram a refazer os originais de seus colegas de outros países de língua castelhana e produzir textos que seriam por sua vez transformados. Logo passaram a imprimir a marca brasileira com adaptações mais aproximadas da realidade do telespectador (MOGADOURO, 2007, p. 89).

Em 1969, a TV Tupi exibiu Beto Rockfeller, de Bráulio Pedroso, que marcou o início de mudanças radicais nas tramas televisionadas ao retratar o cotidiano dos brasileiros, estabelecendo a configuração da novela "como um produto diferenciado das matrizes que o geraram" (MARQUES DE MELO, 1988, p. 27). De acordo com Mogadouro (2007), o sucesso confirmou aos produtores a força do gênero, assim como mostrou que o público desejava uma linguagem mais moderna e comum à classe média urbana. 
Depois da Rede Tupi, outras emissoras de televisão surgiram. Embora tenham produzido telenovelas, sua programação jamais se estruturou em torno desse gênero. A Rede Record, por exemplo, criada em 1953, conquistou grande prestígio, na década de 1960, ao privilegiar a música popular brasileira, com a qual passou a ser identificada nesse período, embora também tenha investido na ficção seriada a partir de 1964 devido ao sucesso das telenovelas no Brasil (FADUL, 1999).

Segundo Fadul, "o surgimento da Rede Globo em 1965 vai ter uma influência muito grande na história da telenovela no país porque ela encontrou na telenovela o ponto de partida para o seu sucesso, assim como a Televisa, do México, e a Rádio e Televisão Caracas, da Venezuela. Tendo se voltado inicialmente para a conquista do mercado interno, a partir de 1975 ela se volta também para o mercado internacional" (FADUL, 1999, p. 3). A Rede Globo de Televisão é referência na produção da telenovela no país. Antes dela apenas a TV Excelsior havia concebido a televisão do ponto de vista empresarial: criou o primeiro cast, valorizou equipes de produção, ofereceu bons salários e foi pioneira ao criar departamentos de figurinos e de cenografia (MOGADOURO, 2007).

As três grandes redes de TV criadas após 1965 produziram telenovelas em diferentes momentos, mas essa nunca foi a atividade principal dessas emissoras. A Rede Bandeirantes, emissora de São Paulo, iniciou a produção de telenovela no ano em que surgiu - 1967. Produziu 26 telenovelas até 1983, quando passou a investir com maior ênfase em esporte e telejornalismo. Com a chegada das TVs por assinatura, na década de 1990, seu público passou a procurar outras alternativas de programação, o que a obrigou a retornar à ficção televisiva buscando atrair outros públicos, mas sem criar um centro próprio de produção (FADUL, 1999). O Sistema Brasileiro de Televisão (SBT) surgiu em 1981. De acordo com Fadul, para agradar o público conservador, que se chocava com as temáticas modernas das telenovelas da Globo, passou a produzir telenovelas a partir de roteiros mexicanos. Em 1985, a emissora interrompeu a produção de novelas por não ter alcançado o sucesso esperado e passou a importar telenovelas do México e da Venezuela. Após período de razoável audiência o público perdeu o interesse pelas novelas importadas e o SBT retomou a produção de novelas na década de 1990. A Rede Manchete surgiu em 1983 e também produziu novelas - algumas das quais alcançaram relativo sucesso e chegaram a ser vendidas para outros países (Ibid.).

Como já foi mencionado, as transmissões da Rede Globo de Televisão foram iniciadas em 1965. Marques de Melo (1988, p. 13) informa que a concessão do canal foi feita pelo governo federal ao final do ano de 1957, mas "a estruturação da emissora (importação de equipamento, construção do edifício, treinamento de pessoal, etc.) durou oito anos". A partir de mudanças introduzidas pela TV Tupi, a Rede Globo foi responsável pela industrialização da telenovela, transformando-a em produto cultural lucrativo e consolidando a especificidade da tele-ficção brasileira. A associação com o grupo Time- $L i$ - 
fe e a criação da Central Globo de Produção foram fatores decisivos pelo altíssimo investimento na sua programação e o estabelecimento do chamado "Padrão Globo de Televisão" (MOGADOURO, 2007).

$\mathrm{Na}$ mesma época, o governo militar promoveu a implantação do sistema de telecomunicações da Embratel e a rede televisiva passou a cobrir quase todo o país (MOGADOURO, 2007). Adite-se ainda o processo de urbanização ocorrido, além do aumento significativo das aquisições de televisores pela classe média urbana. Os programas eram pensados conforme o horário e a faixa etária, o que passou a ser de profundo interesse dos anunciantes. $\mathrm{O}$ estabelecimento da grade de programação com horários fixos e bem divulgados foi fundamental para firmar o hábito do telespectador e a novela global passou a ser mania nacional.

Em 1970, a Rede Globo passou a contar com Janete Clair, que se tornou a novelista mais importante da época, e com Dias Gomes, autor já consagrado no teatro. Aos poucos a Globo tornou-se líder absoluta e desbancou a TV Tupi, extinta em 1980, passando a monopolizar a produção da telenovela, ainda que algumas outras emissoras as produzissem esporadicamente (FADUL, 1999).

Até meados da década de 1970, o público das novelas era composto, em grande maioria, por mulheres de classe média (CAMPEDELLI, 1985), reproduzindo a configuração observada em relação aos folhetins, às radionovelas e às fotonovelas. $\mathrm{O}$ barateamento dos aparelhos de TV ampliou a dimensão do público telespectador, e a diversificação e a atualização temática dos enredos alteraram o perfil desse público, incorporando aos poucos os homens e os adolescentes de ambos os sexos. Trata-se de incorporação gradativa, mas um marco importante foi o momento em que a ficção seriada passou a tratar do reexame das relações entre homens e mulheres (NARLOCH, 2005), ou seja, passou a também explorar assuntos do universo masculino, expondo fragilidades e receios do homem moderno.

A origem da programação ainda hoje vigente, apoiada em noticiário e novela ocupando o horário nobre, situa-se no início dos anos 1970, quando foi lançado o Jornal Nacional e uma novela produzida dentro do padrão que veio a se consagrar com o passar dos anos: a novela Irmãos Coragem (FILHO, 2001). Esse padrão envolve enfocar acontecimentos do dia a dia, aí incluídos os problemas familiares e algumas questões sociais relevantes para a discussão dos fatos narrados. Irmãos Coragem envolvia ambiente rural. A oscilação entre ambientes rural e urbano marcou o início dos anos 1970. Campedelli considera que a opção definitiva pelo ambiente urbano em termos de novelas do horário nobre só veio a ocorrer em 1975, quando iniciou-se a exibição da novela Pecado Capital, (de Janete Clair), e assinala ainda que nessa novela, apoiada em realidade típica da cidade do Rio de Janeiro, emergiu a "dicotomia subúrbio / zona sul carioca" (CAMPADELLI, 1985, p. 63), que tantas outras vezes estaria presente nas novelas da Rede Globo. 
A partir do início dos anos 1970 as novelas passaram a enfatizar o uso da linguagem coloquial, os cenários urbanos e contemporâneos, e situações de fato vividas no País. As tramas são movidas por conflitos amorosos, similaridades e diferenças de concepções entre gerações e entre classes sociais, assim como entre mundo rural e mundo urbano. Campedelli (Ibid.) lembra que fez sucesso, em 1970, a novela Véu de Noiva, cuja publicidade nos jornais, em outdoors, e em chamadas diárias na TV, enfatizava precisamente tratar-se de trama "onde tudo acontece como na vida real". O enredo foi desenvolvido em "ambientação urbana, com núcleos dramáticos divididos entre a classe rica alta, a classe média e o proletariado" (Ibid., p. 59).

\section{Telenovela e contexto sociocultural}

Priolli (2002) lembra que, em termos culturais, consolidaram-se no Brasil padrões de relacionamento interpessoal mais modernos, no sentido de menos presos às tradições do que em outros países da América Latina, o que está refletido nas novelas aqui produzidas, tornando-as mais realistas que as mexicanas, para citar um exemplo de país que também produz muitas novelas para televisão. Essa modernidade explica parte do interesse do público independente de sexo, idade, classe social, e até mesmo, dentro de certos limites, de formação cultural.

Aos poucos configurou-se a situação de cada capítulo ser acompanhado e esperado com expectativas em muitos domicílios. A audiência da novela apresenta pontos de contato com uma "torcida" esportiva, no sentido de satisfazer-se com as realizações de seus personagens preferidos. As pessoas se sentem motivadas a acompanhar a trama devido à existência de uma rede de especulações sobre o caráter e as ações dos personagens. Hamburger diz:

Essa rede de comentários cotidianos constitui a base da audiência da novela e propicia que telespectadores sintetizem experiências públicas e privadas. Em suas conversas sobre a novela, as pessoas expressam divergências e convergências de opinião sobre as ações de personagens e desdobramento de histórias. Suas posições individuais se relacionam com outros conflitos e alianças vividos em seus dramas privados (HAMBURGER, 1998, p. 482).

Pode ser acrescentado a tal aspecto o fato do público também buscar reconhecer-se no cotidiano ficcional apresentado pela telenovela.

A constante presença [dos personagens da novela] via imagem e som torna-os familiares e íntimos. A repetição reforça o apelo identitário que se baseia na mobilização de afetos. A novela é um discurso compensatório que trata de noções abstratas como o mal, o amor, a felicidade, e onde se organizam e se resolvem 
afetos de personagens junto a um público que encontra nas intimidades e nas soluções oferecidas pelas imagens, diferentes níveis de gratificação e que acredita na autoridade na narração televisiva (LEAL, 1986, p. 48).

Sobre a mencionada familiaridade dos personagens da novela, Marques de Melo argumenta: "Como se a distância entre a televisão e o telespectador fosse aquela que separa dois vizinhos que se vêem todos os dias de suas janelas e trocam informações, fofocas e conselhos" (1988, p. 53). Almeida (2003), no mesmo sentido, aponta o processo de reflexividade que ocorre na experiência do espectador de novelas:

Pelas comparações que fazem entre os personagens e as pessoas com quem convivem em suas vidas cotidianas, pela aproximação que sentem com certos personagens ou certas situações vividas por eles, é possível notar como os espectadores revêem a si mesmos, colocam-se em diálogo com a narrativa. Os espectadores discutem muito o que vêem na novela - mesmo que por vezes o façam de modo irônico, distanciado ou distraído, como se a novela não fosse assunto sério. (...) Muitas vezes conversam sobre o que fazem os personagens como se eles fossem pessoas conhecidas, vizinhos, amigos, parentes, e assim comparam o que se passa na narrativa com o que se passa na vida cotidiana das pessoas conhecidas e de si próprios. A passagem da novela para a vida das pessoas conhecidas é fácil e recorrente, e serve inclusive para que as mães discutam com suas filhas temas delicados como sexualidade e relações amorosas (ALMEIDA, 2003, p. 211).

Lopes (2009) considera que, a partir da década de 1990, as telenovelas adotaram um estilo de linguagem naturalista, passando a tratar os temas com uma forte representação "naturalista" em que o discurso é identificado pela própria realidade/verdade. Assim, as tramas ganharam em verossimilhança, credibilidade, legitimidade e mesmo certa "força pedagógica" em relação à comunidade que a consome. Hamburger assim se manifesta sobre o tema:

A televisão, principalmente por meio das novelas, capta, expressa e alimenta as angústias e ambivalências que caracterizam essas mudanças, se constituindo em veículo privilegiado da imaginação nacional, capaz de propiciar a expressão de dramas privados em termos públicos e dramas públicos em termos privados (HAMBURGER, 1998, p. 458).

É surpreendente a diversidade de temas tratados nas novelas e que exemplificam a influência que ela pode ter sobre o cotidiano dos espectadores. Talvez os mais marcantes, paralelamente à criação de inúmeros modismos, sejam aqueles da esfera do merchandising social, muitas vezes associados 
com campanhas e providências que se concretizam no mundo real. Podem ser citados: enfrentamento de doenças, doação de órgãos, dependência de drogas, desaparecimento de crianças, violência familiar, direitos de portadores de necessidades especiais, diferentes formas de preconceito, exploração do trabalho infantil, entre outros.

Em relação a tal assunto está em jogo o processo que Lopes denomina de "hibridação de ficção e realidade" $(2009$, p. 32). A prática de merchandising social pode ser vista como forma de publicidade educativa, não comercial (em si mesma, mas com reflexos comerciais em termos de audiência), que objetiva preencher lacunas de conhecimento. A alta frequência com que são abordados assuntos que demandam participação de profissionais especializados torna possível dizer que o merchandising social tal como praticado nas novelas tem similaridade com a divulgação científica, com alcance amplo em decorrência da elevada audiência e com a capacidade adicional de criar situações concretas de mobilização populacional pelo domínio técnico das cenas que são elaboradas de forma eficiente em relação ao objetivo de conseguir atingir emocionalmente os telespectadores. Como exemplos adicionais, marcantes da reação de natureza institucional no mundo real em resposta à ficção televisiva, podem ser mencionadas situações em que dispositivos legais foram aperfeiçoados ou aprovados em contexto influenciado por telenovelas em exibição, como registrado por Lopes (2009).

Deve ficar claro que a menção à incorporação de temáticas variadas nas tramas das telenovelas não significa que tais temas sejam centrais. As tramas permanecem apoiadas nos mesmos elementos tradicionais abordados nos folhetins românticos, com adaptações necessárias à realidade econômica e cultural brasileira, com extenso segmento populacional de baixa escolaridade, assimetria socioeconômica expressiva quando comparados distintos estratos, casamento como meta de vida e como oportunidade de melhorar de vida, entre outros aspectos. Marques de Melo, escrevendo em 1988, assinalou que as tramas das telenovelas envolvem:

[...] três elementos capazes de viabilizar a identificação e a participação do conjunto dos telespectadores: uma linguagem coloquial (de fácil entendimento para todos), a escolha de personagens da classe média (com os quais o contingente majoritário da audiência se identifica, seja porque se vê refletido, seja porque constitui um padrão socioeconômico desejável) e, finalmente, a presença do mito da ascensão social (catalisador dos anseios e aspirações de uma população predominantemente jovem, esperançosa pela partilha das benesses de que já desfrutam os personagens do folhetim eletrônico) (MARQUES DE MELO, 1988, p. 52).

Os índices de audiência alcançados indicam que o telespectador deseja que certos aspectos da realidade cultural nacional, em especial os conflitos fami- 
liares, as angústias, as alegrias e as expectativas pessoais de fato vivenciadas pelos brasileiros sejam retratados com maior tolerância para as soluções de desfecho encontradas pelo autor, quando os limites da plausibilidade e da realidade podem ser colocados em segundo plano. A retratação de tais aspectos proporciona o reconhecimento necessário para que o telespectador legitime uma produção como a telenovela, considerada ao mesmo tempo tão próxima e tão irreal ao cotidiano de cada um (MARTIN-BARBERO; MUNÕZ, 1992). É claro que a novela é um produto comercial do qual muitos temas da realidade nacional estão ausentes, sendo que talvez o grande tema omitido seja a política, como ressalta Ribeiro (2005), pois mesmo que apareçam políticos como personagens ou que a corrupção política seja abordada, o interesse maior está nas relações privadas dos indivíduos.

De acordo com os temas abordados o receptor pode fazer uma generalização de contexto, transportando o conteúdo observado para a realidade de seu cotidiano pessoal ou de seu grupo de referência. Ao retratarem aspectos reconhecíveis da realidade na ficção, as novelas objetivam assegurar a identificação de ampla parcela da audiência, mas é claro que isso ocorrerá conforme as modulações de interesse e de aceitação decorrentes das experiências de vida, dos estilos, dos costumes e da visão de mundo de cada indivíduo - receptor. Como ressalta Cuche (1999, p. 159), "por mais padronizado que seja o produto de uma emissão, sua recepção não pode ser uniforme e depende muito das particularidades culturais de cada grupo, bem como da situação que cada grupo vive no momento da recepção".

O poder de atração das novelas sobre o público não resulta só de estarem sendo retratados fatos reais ou um cotidiano reconhecível. De acordo com Leal, "A imagem e a fala da novela das oito que saem do aparelho televisivo fazem parte do sistema de significados que a reconhece como poder. A novela para o grupo popular é ficção realista e é realidade cotidiana na casa de cada um" (1986, p. 87). Tal perspectiva corrobora a ideia da impossibilidade da recepção uniforme. Borelli assim se manifesta a respeito:

\footnotetext{
[...] Portanto, o papel do receptor, leitor ou espectador não pode ser encarado como passivo, iludido ou alienado. O telespectador é um sujeito ativo, consciente. Ativo pela existência de uma série de normas que acionam o imaginário. Participantes na construção das imagens, reconhecimento de sinais, preenchimento de lacunas e reconstituição de um estilo familiar, conhecido. Capazes de perpetuar, redefinir padrões, de apropriar-se dos gêneros e transformá-los em referências ao mesmo tempo particular e universalizantes (BORELLI, 1994, p. 82).
}

Percebe-se que o processo envolvido é ainda mais complexo quando se leva em conta que existe o compromisso constante de ajustar os acontecimentos da trama a determinadas formas de repercussão, ou seja, a determinados parâmetros de avaliação, em tempo real, de diferentes segmentos so- 
ciais. Como destaca Mendes, os papéis de quem produz e de quem recebe o conteúdo veiculado se alternam e se confundem, em certa medida, uma vez "que a telenovela não é um discurso totalmente predefinido, estando sempre em reelaboração, ou seja, os papéis temáticos dos atores discursivos e seus programas narrativos podem se transformar e até mesmo mudar, ao longo da narrativa, por conta das pesquisas de opinião junto aos telespectadores" (MENDES, 2008, p. 276). Tal condição decorre do fato de a telenovela ser escrita no mesmo período em que vai ao ar, ou seja, ela é uma obra que permite interatividade entre o autor e o público. A respeito desse tema, Mogadouro argumenta:

\begin{abstract}
A telenovela conquistou mecanismos de interatividade que fazem com que a sua assistência se transforme numa experiência não apenas cultural, mas de sociabilidade, uma vez que ativa um repertório compartilhado e faz circular discussões que se entrecruzam com o que se divulga na imprensa escrita, nos vários programas de televisão e de rádio, nas pesquisas de audiência, e nas conversas domésticas, entre vizinhos, em ambientes de trabalho e escolares (MOGADOURO, 2007, p. 92).
\end{abstract}

Mendes aponta outra faceta importante da hibridação entre ficção e realidade que pode auxiliar a explicação da ampla aceitação das telenovelas:

\begin{abstract}
Mas há um outro aspecto, que não é específico da telenovela, pois está presente em todo tipo de narrativa ficcional: uma sensação de poder, que nos iguala ao criador do discurso, tornando-se assim semelhante ao poder divino dos deuses, fadas e bruxas. Trata-se da onisciencia, ou seja, a capacidade de ver e saber tudo que acontece em todos os lugares ao mesmo tempo. Enquanto os atores do discurso, mocinhos ou bandidos, heróis ou traidores, não sabem o que acontece na sua ausência, nós sabemos, tanto quanto os autores da trama e, por isso podemos julgá-los e até mesmo antegozar os prêmios ou castigos que virão (MENDES, 2008, p. 279).
\end{abstract}

Mesmo reconhecendo que a telenovela brasileira incorpora em sua trama elementos de divergência e de conflito, não se pode esquecer que ela está apoiada em certa concepção de ordem social e de moralidade que, como ressalta Gomes (2002), está comprometida com a ideia de harmonia e de respeito a um determinado modelo de hierarquia. Faz-se aqui uma digressão para mencionar um aspecto curioso, embora compreensível em função da exigência de que os personagens estejam em ação nas tramas: o dia a dia das famílias retratadas nas telenovelas não inclui as próprias telenovelas. Os integrantes das famílias retratadas exibem muitos comportamentos e padrões de relacionamento reconhecíveis de imediato como plausíveis no contexto cotidiano do brasileiro, mas não assistem telenovelas em momento algum. 
Todos os aspectos mencionados até aqui concorreram para que a telenovela brasileira se tornasse produto ficcional de massa reconhecido como legítimo e fascinante pela sociedade. E, embora por muito tempo as telenovelas tenham sido ignoradas pelos pesquisadores, também passaram a ser alvo de estudos acadêmicos desenvolvidos no país - realidade hoje consolidada. Marques de Mello (1998) vale-se de citação de Muniz Sodré para propor que o segredo da telenovela reside na combinação de dois ingredientes: a ficção sem fantasia e uma moral doméstica. Diaz, Mantecón e Mantecón (1995) usaram expressão inventiva para caracterizar a ambiguidade ficção/realidade no contexto das telenovelas, ao dizerem que elas são a ficção que se chama realidade. Esses autores destacam que assistir televisão é, em si mesmo, um ato social que não remete apenas a uma forma de uso do tempo livre, mas também a uma maneira de participar da sociedade, proporcionando um denso tecido de experiências que nutrem as relações sociais cotidianas (práticas, códigos comuns, configuração de identidades e pertenças grupais).

Como ilustração da transformação do interesse acadêmico pelos telenovelas, registra-se o caso de importante pensador (Renato Janine Ribeiro) que, em textos sobre conteúdo e repercussões da televisão brasileira reunidos em publicação de 2005, afirmou defender as novelas contra a opinião de muitos de seus colegas acadêmicos. Segundo ele, algumas das características das telenovelas a serem valorizadas devem-se ao fato de que:

\begin{abstract}
Têm papel positivo na transmissão de certos ideais, em especial o da igualdade da mulher em relação ao homem e o da condenação do preconceito racial. É claro que a TV é menos profunda ou pioneira que os grupos feministas ou de consciência indígena ou negra - mas só ela pode levar uma idéia, um nome de livro, um comportamento a 50 ou 60 milhões de pessoas"; (...) É o gênero de nossa TV que melhor exprime um ideal de justiça e um sonho de felicidade; (...) "Sua qualidade está em discutir os costumes. Se a TV brasileira não abre uma discussão política séria e, portanto, não concorre para a democracia política, pelo menos, com a novela, ela contribui para mexer nos sentimentos das pessoas"; (...) "É o gênero dramático em que o Brasil melhor se saiu. Nela não ouvimos discursos: presenciamos situações. A dramaturgia funciona mais que a palavra seca. Daí seu alcance social. Por isso é errado dizer que a TV não educa. Ela varreu preconceitos de costumes" (RIBEIRO, 2005, p. 21-40).
\end{abstract}

É sabido, como confirmam informações já mencionadas no texto, que a novela é a mais longeva e bem-sucedida produção da televisão brasileira. Ela não só incorpora aspectos da vida social real, mas também produz efeitos concretos na sociedade, inclusive fatos que passam a ser noticiados em toda a imprensa, muitas vezes caracterizando um jogo ambíguo de interesses comerciais mútuos. 
No início da década de 1970, Maxwell McCombs e Donald Shaw, a partir da constatação de que pessoas expostas a certos meios de comunicação de massa davam muita atenção e atribuíam grande importância exatamente àquelas questões que esses meios de comunicação destacavam como importantes (PAVARINO, 2003), desenvolveram uma proposição de interesse para o tema. Trata-se da hipótese de Agenda Setting, segundo a qual os meios de comunicação de massa são "o principal elo entre os fatos e a opinião pública, entre o real, o compreendido e o imaginado (...) direcionando a opinião pública, dando sentido à realidade social" (PAVARINO, 2003, p. 11) e, de certa forma, dizendo ao público sobre o que pensar e como pensar sobre isso. A hipótese de Agenda Setting, como o nome indica, é a de que os meios de comunicação de massa estabelecem pautas para a vida social, destacando assuntos que serão objeto do interesse de quem a eles tem acesso.

\section{Considerações finais}

Os proponentes da hipótese de Agenda Setting acreditam que o efeito de impor pautas à vida social evidencia o poder que os meios de comunicação exercem sobre as concepções das pessoas a respeito de inúmeros assuntos. Vale ressaltar, entretanto, que os meios de comunicação não podem manipular toda e qualquer informação salientando ou omitindo aspectos selecionados por qualquer critério que seja; não basta um editor decidir que um assunto será privilegiado para ele alcançar a proeminência a que se refere a hipótese. $\mathrm{O}$ estabelecimento de pautas com os temas que se tornarão parte relevante das conversas e discussões cotidianas na família, na escola, no trabalho, e nas situações de lazer deve corresponder ao potencial de reação que o teor da novidade poderá estimular ou, em outros termos, com o nível de amadurecimento e de abertura para a assimilação de concepções como a que esteja em jogo por parte daquele público. Essas condições, de alguma forma, são monitoradas o tempo todo, tornando possível falar em um processo bidirecional quase óbvio: Os meios de comunicação de massa elegem assuntos dos quais os grupos se ocuparão, mas a matéria-prima é quase sempre a presença de fragmentos desses assuntos nas interações desses mesmos grupos.

$\mathrm{O}$ argumento mencionado acima é o ponto de partida para a proposição que o presente estudo elabora. Existe um assunto que é parte do dia a dia de todos os espectadores e que está presente em todas as novelas. Esse assunto se apresenta sob diferentes facetas na vida real e é tratado com diversificação nas telenovelas. Tal assunto é a família, o que engloba suas configurações, relações interpessoais e inter-geracionais, assim como as várias ocorrências associadas à vida conjugal.

As novelas retratam tradições, mudanças e inovações, normalmente pela via de inclúi-las nas vivências e preocupações dos diversos núcleos familiares que fornecem a estrutura para o desenrolar da trama, e que são caracterizadas como famílias compreensíveis para os telespectadores como possíveis 
na realidade brasileira. Marques de Melo (1998) diz que tal apropriação do real se faz em torno de parâmetros morais da instituição familiar (sem que haja adesão automática a eles), ajustando conteúdos ideológicos, sentimentos, costumes e tendências já existentes socialmente, ainda que em alguns casos estejam em jogo costumes ou tendências recentemente surgidos. Dessa forma, a novela inclui temas que já circulam na sociedade, e entre eles alguns que são delicados pelo potencial de transformação de valores e tradições que implicam.

Nesse processo de valorização de temas cuja aproximação com a realidade seja evidente nota-se, por exemplo, a presença constante de arranjos familiares novos, em contextos que retratam parte do espectro das desigualdades sociais, além de situações de discussão e superação de preconceitos, de intolerâncias, de tradições autoritárias, o que gera debate e reflexão entre espectadores.

Considerações similares, enfatizando que a família é utilizada na trama como ambiente para a manutenção do padrão tradicional do folhetim, foram apresentadas por Lopes (2009), ao assinalar que a telenovela aborda diversas instâncias da realidade, mas é o comportamento e as questões morais que mais chamam a atenção, e todo o conteúdo está investido dessa matriz narrativa. O reconhecimento do público acontece porque todo mundo se vê numa família.

Não é razoável pretender que a novela aborde quaisquer temas (o que inclui a família) de forma a retratar com exatidão o que ocorre na sociedade, posto tratar-se de produto ficcional cuja sustentação é comercial e que precisa atender aos diversos constrangimentos impostos no caminho de sua aceitação (preferências e compromissos de autores, estilos de diretores, características de atores, aceitação pelo público, reações de entidades organizadas, proteção de interesses dos anunciantes, auto-censura ou censura antecipada, entre outros). Porém, ao expor publicamente, e trazer à discussão alguns assuntos pertinentes ao âmbito familiar que são pouco explorados ou explorados apenas por segmentos específicos da sociedade, a novela está exercendo importante função dos meios de comunicação de massa. Tal função é reforçar a presença e a dissonância que tal assunto produz no senso comum, contribuindo para o processo de transformação do não-familiar em familiar (PAVARINO, 2003).

É importante destacar que a telenovela no Brasil, além de focalizar diversos assuntos polêmicos relacionados à família brasileira, o tem feito com características que contestam a rigidez das tradições, ainda que sempre aos poucos, em pequenas doses, com avanços e recuos. Alguns exemplos dessa precavida e dosificada contestação da rigidez das tradições são mencionados a seguir.

Um dos aspectos introduzidos na forma como a família brasileira vem sendo retratada na ficção televisiva é o da existência de arranjos familiares e conjugais incomuns (ou ocultados) há algumas décadas, mas com ocorrência atual expressiva. É certo que não se descarta a idéia de que existe uma unidade 
ideal - família - que, em si mesma, é um valor a ser preservado. Admite-se, entretanto, que tal família não precisa obedecer a modelo único e que, mesmo discrepando do padrão consolidado culturalmente, pode ser reconhecida como uma família que preserva as mais importantes qualidades que dela se espera (ainda que viva conflitos eventuais).

Outro exemplo é o fato da perspectiva tradicional homem provedor e mulher responsável por atividades do lar e criação dos filhos não mais aparecer como única possibilidade. São inúmeros os casos de casais (quase sempre com poucos filhos) em que marido e mulher têm atividades profissionais e são co-provedores. Decorrem daí transformações substanciais nas relações de autoridade no âmbito da família que são compartilhadas pelos cônjuges. Ambos decidem sobre a criação dos filhos e a definição dos valores morais a serem privilegiados. Sobre o exercício da autoridade, na esfera das relações pais e filhos, não mais aparecem - exceto em novelas de época - situações de autoridade absoluta dos pais (ou do pai), embora possam ser retratadas situações específicas em que os pais tentam impor aos filhos suas concepções, sua compreensão de moralidade e mesmo seus interesses.

Uma das grandes transformações culturais vividas no país nas últimas décadas, devidamente captada e explorada nas novelas, diz respeito à sexualidade, que é apresentada de forma muito mais saudável do que já ocorreu no passado; como exercício que faz parte da conquista da autonomia pessoal e da construção de projetos e escolhas no âmbito afetivo. Casamentos, descasamentos e recasamentos são episódios que podem ser vividos por personagens tanto com banalidade como com reflexão. Podem por vezes envolver evidente satisfação e entendimento, mas também podem envolver desentendimentos e equívocos e serem superados, ou seja, não precisam ser encarados como acontecimentos definitivamente limitadores.

O presente texto é encerrado com a retomada e a reafirmação do argumento já delineado antes: a centralidade de questões sobre realidade e transformações da família brasileira nas telenovelas é aspecto imprescindível na discussão do sucesso e da longevidade dessa modalidade de produção cultural que há meio século marca profundamente a cultura brasileira. As telenovelas, ao explorarem as fragilidades da região fronteiriça entre tradições e contradições, contribuíram de forma expressiva para dificultar a permanência das relações familiares de alguns segmentos populacionais do país na condição de imutabilidade.

\section{Referências Bibliográficas}

ALMEIDA, Heloísa Buarque de. Telenovela, consumo e gênero - "muitas mais coisas". Bauru: Udusc/Anpocs, 2003.

BERWANGER, Dietrich. 'The Third World'. In: SMITH, Anthony (Ed.). Television: an International History. New York: Oxford University Press, 1995. p. 309-330. 
BORELLI, Silvia Helena Simões. Gêneros ficcionais: matrizes culturais no continente. In: BORELLI, Silvia Helena Simões (Org.). Gêneros ficcionais, produção e cotidiano na cultura popular de massa. São Paulo: Intercom/CNPq/Finep, 1994.

BUITONI, Dulcília Schroeder. Imprensa Feminina. São Paulo: Ática, 1986.

CAMPEDELLI, Samira Youssef. A telenovela. São Paulo: Ática, 1985.

CUCHE, Denys. A Noção de cultura nas ciências sociais. Bauru: Unisc, 1999.

CUNHA, Maria Teresa Santos. Armadilhas da sedução - os romances de M. Delly. Belo Horizonte: Autêntica, 1999.

DEJAVITE, Fabia. A Telenovela na grande imprensa nacional: um estudo exploratório da Folha de São Paulo e da Veja. Revista Ceciliana,[S.1.], n. 12, p. 27-38, 1999.

DÍAZ, Miguel Angel Aguillar; MANTECÓN, Ana Rosas; MANTECÓN, Verônica Vásquez. Telenovelas: la ficción que se llama realidad. Política y Sociedad, [S.1.], n. 4, p.173-185, 1995.

FADUL, Anamaria. Telenovela e família no Brasil. In: Congresso Brasileiro de Ciências da Comunicação, 22, Rio de Janeiro, 1999. - Grupo de Ficção Televisiva Seriada. Anais...Rio de Janeiro, 1999.

FILHO, Daniel O Circo Eletrônico: Fazendo TV no Brasil. Rio de Janeiro: Jorge Zahar, 2001.

GOMES, Laura Graziela. Telenovela e Cultura da harmonia. In: KUNSCH, Margarida Maria Krohling; FISCHMANN, Roseli (Orgs.) Midia e Tolerância. São Paulo: Edusp, 2002, p. 75-88

HABERT, Angeluccia Bernardes. Fotonovela e indústria cultural. Petrópolis: Vozes, 1974.

HAMBURGER, Esther. Diluindo Fronteiras: a televisão e as novelas no cotidiano. In: SCHWARCZ, Lilia Moritz. (Org.) História da vida privada no Brasil. São Paulo: Companhia das Letras, 1998. v. 4, p. 439-487.

LEAL, Ondina Fachel. A Leitura Social da Novela das Oito. Petrópolis: Vozes, 1986.

LOPES, Maria Immacolata Vassallo. Telenovela como recurso comunicativo. Matrizes, [S.1.], v.3, n.1, p. 21-47, 2009.

LOPES, Maria Immacolata Vassallo; BORELLI, Silvia Helena Simões; RESENDE, Vera da Rocha. Vivendo com a telenovela: mediações, recepção, teleficcionalidade. São Paulo: Summus, 2002.

MARCONDES FILHO, Ciro. Televisão. São Paulo: Scipione, 1994.

MARQUES DE MELO, José. As telenovelas da Globo - produção e exportação. São Paulo: Summus, 1988.

Teoria da Comunicação: Paradigmas Latino-Americanos. Petrópolis: Vozes, 1998.

MARTIN-BARBERO; Jesús; MUNÕZ, Sonia. Televisión y melodrama. Bogotá: Tercer Mun- 
do, 1992.

MENDES, Mariza Bianconcini Teixeira. A ficção seriada na TV brasileira: uma prática sociossemiótica. Estudos Lingüísticos, São Paulo, v. 37, n. 3, 273-280, set./dez. 2008.

MOGADOURO, Claudia de Almeida. A Telenovela brasileira: uma nação imaginada. Eco-Pós, v.10, n. 2, p. 85-95, 2007.

NARLOCH, Leandro. A voz do Brasil. Super Interessante, n. ${ }^{\circ}$ 219, p. 48- 57, 2005.

PATERSON, Richard. Drama and Entertainment. In: SMITH, Anthony (Ed.). Television: an International History. New York: Oxford University Press, 1995. p. 95-117.

PAVARINO, Rosana Nantes. Teoria das Representações sociais: pertinência para as pesquisas em comunicação de massa. In: Congresso Brasileiro de Ciências da Comunicação, 26, Belo Horizonte. 2003. Anais...Belo Horizonte: Intercom, 2003. p.1-20.

PRIOLLI, Gabriel. A Deusa Ferida: Porque a Rede Globo não é mais a Campeã Absoluta. São Paulo: Summus, 2002.

RIBEIRO, Renato Janine. Afeto Autoritário: Televisão, ética e democracia. Rio de Janeiro: Ateliê Editorial, 2005.

TELLES, Norma. Escritoras, escritas, escrituras. In: PRIORE, Mary Del; BASSANEZI, Carla (Orgs.) História das mulheres no Brasil. São Paulo: Contexto / UNESP, 1997. p. 401-442.

TORRES, Fernando. A novela nossa de cada dia. Canal da Imprensa - Revista eletrônica do curso de Jornalismo do Unasp, [S.1.] n ${ }^{\circ}$ 19, s/p, 2003. Disponível em: $<$ http://canaldaimprensates.wix.com/canaldaimprensa\#!quem-somos/c243z> Acesso em: 11 nov.2013.

\section{Agradecimento}

À agência de fomento: CNPq.

Submissão em: 15/12/2013

Revisão em: 25/03/2014

Aceite em: 30/03/2014

Paulo Rogério Meira Menandro. Doutor em Psicologia. Professor Titular da Universidade Federal do Espírito Santo. Bolsista de Produtividade em Pesquisa do CNPq. Endereço para correspondência: PPGP/UFES. Av. Fernando Ferrari, 514. Goiabeiras. Vitória/ES CEP 29075-910. E-mail: paulomenandro@uol.com.br

Cinthia Ferreira de Souza. Mestre em Psicologia. Faculdade Pitágoras. Grarapari/ ES, Brasil. E-mail: cinthia2007@gmail.com 